\title{
Facet of Food Security under NREGA in Sikkim
}

\author{
Debashis Sarkar*, Jiban Kumar Ghosh and Snehasish Karmakar
}

AER Centre, Visva-Bharati, Santiniketan, Birbhum-731236, West Bengal, India

*Corresponding author: debashis.sarkar@visva-bharati.ac.in

\begin{abstract}
NREGA became operational from February 2006 in Sikkim. An effort has been made in this paper to identify the factors determining the participation of people in NREGA scheme and to see whether NREGA has been successful in ensuring better food security to the beneficiaries. It has been found that there is considerable amount of variation across the households in the consumption of food and non-food items between beneficiary and non-beneficiary households under NREGA. The average household consumption expenditure is lower than household income both for beneficiary and non-beneficiary households. There are however variations in income and consumption across the households and the extent of variation being greater for non-beneficiary households. There is relatively greater inequality in the income earned in case of non-beneficiary households, which is indicative of the fact that non-beneficiaries have derived income from occupations diversified in nature. The level of education and sex are positively related to NREGA participation.
\end{abstract}

Keywords: NREGA, income, expenditure, consumption, education, sex, Sikkim

The National Rural Employment Guarantee Act (NREGA) was enacted in 2005 to provide a guaranteed wage employment of 100 days in every financial year to every household whose adult members volunteer to do unskilled manual work. It goes beyond poverty alleviation and recognizes employment as a legal right. The act was enacted to enhance livelihood security in rural areas. Through the process of providing employment on works that addresses causes of chronic poverty such as drought, deforestation and soil erosion, the Act seeks to strengthen the natural resource base of rural livelihood and create durable assets in rural areas. The Act is also likely to arrest rural-urban migration.

In India, NREGA was implemented in three phases:

I Phase - notified 200 districts with effect from February $2^{\text {nd }} 2006$.

II Phase - extended to 130 districts in the financial year 2007-08 (113 districts from April $1^{\text {st }} 2007$ and 17 districts of UP were notified with effect from May $15^{\text {th }}$ 2007).
III Phase-remaining districts in all the States/UTs were notified from April $1^{\text {st }} 2008$.

In Sikkim, NREGA became operational from February 2006. The scheme had been introduced in phases. Initially, in the first phase, the scheme was introduced in north Sikkim. In the second phase, from $1^{\text {st }}$ April 2007 two more districts namely, East and South Sikkim districts were brought under its coverage. One more district viz., West Sikkim was added in the third phase from $1^{\text {st }}$ April 2008. Thus, the scheme is operational in all districts of the state of Sikkim w.e.f. $1^{\text {st }}$ April 2008.

There has been a dearth of studies designed to assess the performance of National Rural Employment Scheme ever since the Act came into force in the country (Ambasta et al. 2008; Gopal, 2009; Jha et al. 2008; Mehrotra, 2008; Chakraborty, 2007). While some studies have drawn attention to huge leakage in the implementation of the scheme, namely inflated or fake muster roll entries, embezzlement of funds, non-payment of minimum wages, delayed wage payments beyond the stipulated period of 15 days, non-payment of unemployment 
allowance, irregularities in conduct of social audit etc., others are not that critical, rather have been hopeful in recognizing that the programme effectiveness will increase with experience. With the guarantee of demand-driven fund allocation, NREGA scheme opens up tremendous possibilities of creating a livelihood resource base of the rural poor. The scheme has high expectations in terms of employment generation, alleviation of poverty, food security, halting migration and overall rural development. Based on this background, an effort has been made in this paper to identify the factors determining the participation of people in NREGA scheme and to see whether NREGA has been successful in ensuring better food security to the beneficiaries.

\section{Database and Methodology}

The study has been conducted in Sikkim based on primary data. There are four districts in Sikkim viz. North Sikkim, East Sikkim, South Sikkim and West Sikkim districts with districts headquarters at Mangan, Gangtok, Namchi and Gyalsing respectively. From each district, two villages are selected keeping into account their distance from the main city/town i.e., one village close to the periphery of around 5 kilometers of the district/ city head-quarters and the second one from a farthest location of 20 kilometers or more than that. For selecting participant households, a list of all beneficiaries (participants) of the selected village is obtained from the Gram Panchayat. After getting the list, a Stratified Random Sampling Method is adopted for selection of the participant households by giving proportionate representation to the Caste, i.e. (i) Schedule Caste (ii) Schedule Tribe (iii) Other Backward Caste (iv) Forward Castes (others). A due representation is also given to the gender factor. From each selected village, primary survey is carried out on 20 participants in NREGA and 5 non-participants. Finally, a total of 200 households are surveyed in detail with the help of structured household questionnaire. For the selection of nonparticipants, no such list is available. Therefore, criterion for selecting non-participant households is that these households are not participating in NREGA but constitute the similar caste and gender characteristics as that of the selected participant households.
Overall, the Logit Probit analysis conducted at both household and member levels suggest that a set of socio-economic characteristics of households such as caste, sex, educational attainment, number of members in the household (household size) and employment other than NREGA explain the household's participation status (whether they are participating in NREGA or not). The analysis has also been undertaken with the help of Ordinary Least Square (OLS) method. For OLS regression analysis at household level, number of days per household worked in NREGA is taken as the dependent variable. Among the explanatory variables, four are continuous and others are dummy variables. The continuous variables are employment other than NREGA (number of working days), household income other than NREGA (Rs per household), household size (number), and household assets (Rs per household). The dummy variables are land holding (have land $=1$, otherwise $=0$ ) BPL card holding (having BPL card $=1$, otherwise $=0$ ), schedule caste $(S C=1$, otherwise $=0)$, schedule tribe $(S T=1$, otherwise $=0), \mathrm{OBC}(\mathrm{OBC}=1$, otherwise $=0)$.

\section{RESULTS AND DISCUSSION}

It has been found that there is considerable amount of variation across the households in the consumption of food and non-food items between beneficiary and non-beneficiary households under NREGA and consequently in the per capita intake of food and non-food items in the consumption basket. Variation is measured by the technique of coefficient of variation as it is commonly used in empirical literature. It would be seen from Table 1 that in respect of per capita monthly consumption of food items, variation across the households is low (24.80 per cent) for non-beneficiary households when compared to those of beneficiary households (27.00 per cent). In respect of non-food items too, the variation is high ( 39.20 per cent) in case of beneficiary households and is relatively small (33.70 per cent) in case of non-beneficiary households. As a whole, beneficiary households exhibited high degree of variation in monthly per capita consumption expenditure in food and non-food items across the households in comparison with non-beneficiary households. Within the group of food items, variation in consumption expenditure across households is observed more in non-cereal 
Table 1: Monthly consumption expenditure of households

(Consumption expenditure in ₹)

\begin{tabular}{|c|c|c|c|c|c|c|c|}
\hline \multirow[t]{2}{*}{ Items } & $\begin{array}{l}\text { Monthly per } \\
\text { capita }\end{array}$ & $\begin{array}{c}\text { Coefficient of } \\
\text { variation }\end{array}$ & $\begin{array}{l}\text { Monthly per } \\
\text { capita }\end{array}$ & $\begin{array}{c}\text { Coefficient of } \\
\text { variation }\end{array}$ & $\begin{array}{l}\text { Monthly per } \\
\text { capita }\end{array}$ & $\begin{array}{c}\text { Coefficient of } \\
\text { variation }\end{array}$ & \multirow[t]{2}{*}{$\begin{array}{c}\text { NSS } \\
2004-05\end{array}$} \\
\hline & \multicolumn{2}{|c|}{ Beneficiaries } & \multicolumn{2}{|c|}{ Non beneficiaries } & \multicolumn{2}{|c|}{ Aggregate } & \\
\hline \multicolumn{8}{|c|}{ Food Items } \\
\hline Rice & $146.9(25.1)$ & 26.3 & $142.7(25.0)$ & 24.6 & $146.0(25.1)$ & 25.9 & $91.2(13.9)$ \\
\hline Wheat & $24.8(4.2)$ & 26.4 & $23.5(4.1)$ & 28.9 & $24.5(4.2)$ & 26.8 & $5.8(0.9)$ \\
\hline Other cereals & $14.8(2.5)$ & 29.2 & $13.6(2.4)$ & 26.9 & $14.5(2.5)$ & 28.8 & $5.5(0.8)$ \\
\hline Total cereals & $186.4(31.9)$ & 26.1 & $179.8(31.6)$ & 24.6 & $185.1(31.8)$ & 25.7 & $102.4(15.6)$ \\
\hline Pulses & $21.3(3.6)$ & 29.6 & $19.3(3.4)$ & 31.7 & $20.8(3.6)$ & 30.0 & $14.7(2.2)$ \\
\hline Sugar etc & $10.6(1.8)$ & 31.3 & $10.2(1.8)$ & 27.9 & $10.5(1.8)$ & 30.6 & $7.8(1.2)$ \\
\hline Cooking oil & $17.3(3.0)$ & 34.7 & $15.9(2.8)$ & 23.5 & $17.0(2.9)$ & 32.9 & $33.7(5.1)$ \\
\hline Spices & $6.1(1.0)$ & 40.1 & $5.6(1.0)$ & 29.7 & $6.0(1.0)$ & 38.4 & $5.6(9.3)$ \\
\hline Milk \& prods & $15.8(2.7)$ & 43.2 & $14.2(2.5)$ & 42.3 & $15.5(2.7)$ & 43.1 & $61.5(0.9)$ \\
\hline Poultry-meat & $35.1(6.0)$ & 29.1 & $35.7(6.3)$ & 34.1 & $35.2(6.1)$ & 30.2 & $45.1(6.8)$ \\
\hline Fruits & $3.4(0.6)$ & 46.0 & $0.0(0.0)$ & 0.0 & $2.7(0.5)$ & 46.0 & $5.5(0.8)$ \\
\hline Vegetables & $13.6(2.3)$ & 36.3 & $13.2(2.3)$ & 33.4 & $13.6(2.3)$ & 35.6 & $62.5(9.5)$ \\
\hline Confectionery & $8.5(1.5)$ & 36.4 & $8.3(1.5)$ & 44.2 & $8.5(1.5)$ & 38.0 & $3.5(0.5)$ \\
\hline Total food & $318.1(54.4)$ & 27.0 & $302.2(53.0)$ & 24.8 & $314.8(54.1)$ & 26.6 & $342.3(52.0)$ \\
\hline \multicolumn{8}{|c|}{ Non food items } \\
\hline Education & $22.2(3.8)$ & 74.4 & $17.1(3.0)$ & 123.9 & $21.1(3.6)$ & 74.2 & $14.9(2.3)$ \\
\hline Clothing & $34.9(6.0)$ & 81.0 & $39.4(6.9)$ & 80.6 & $35.8(6.2)$ & 81.1 & $37.8(5.7)$ \\
\hline Footwear & $10.3(1.8)$ & 39.7 & $12.6(2.2)$ & 89.5 & $10.8(1.9)$ & 59.1 & $13.2(2.0)$ \\
\hline Other items & $165.0(28.2)$ & 36.1 & $164.6(28.9)$ & 31.4 & $164.9(28.4)$ & 35.1 & $171.7(26.1)$ \\
\hline Fuel & $34.0(5.8)$ & 26.2 & $34.0(6.0)$ & 27.3 & $34.0(5.9)$ & 26.4 & $78.0(11.9)$ \\
\hline Total Non food & $266.5(45.6)$ & 39.2 & $267.7(47.0)$ & 33.7 & $266.7(45.9)$ & 38.1 & $315.6(48.0)$ \\
\hline Gross total & $584.6(100.0)$ & & $569.9(100.0)$ & & $581.6(100.0)$ & & 657.9 (100.0) \\
\hline
\end{tabular}

Note: Figures in parentheses are respective percentages of gross total.

items both in the case of beneficiary and nonbeneficiary households with relatively higher degree of variation for the former group of households. Estimates of the average household income and consumption during the reference year and their households are presented in Table 2. The estimates of the degree of inequalities (Gini Ratios) in income and consumption are also given in the same table. Broadly speaking, the average household consumption expenditure is lower than household income both for beneficiary and non-beneficiary households. There are however variations in income and consumption across the households as captured by the co-efficient of variation, the extent of variation being greater for non-beneficiary households in income and lower in consumption. The table shows that higher household income is associated with higher degree of variance as it has happened in the case of non-beneficiary households. In contrast, beneficiary households with comparatively lower level of consumption are coupled by higher variance and low level of variation in income. In between household income and consumption, the extent of variation tended to be lower in consumption than in income both in the case of beneficiary and nonbeneficiary households.

The Gini ratio as a measure of inequality does not vary much between income and consumption. In fact, there are no major instances of savings or dis-savings (transfer of income through loans) that could cause the measures of inequality for consumption and income to diverge. The degree of inequality both in income and consumption is low but somewhat varies across both the beneficiary and non-beneficiary households. The Gini ratio shows relatively greater inequality in the income earned 
Table 2: Variability in consumption and income

\begin{tabular}{|c|c|c|c|}
\hline Particulars & Beneficiary & Non beneficiary & Total \\
\hline Average household Income during the reference year (Rs) & 32425.9 & 35508.3 & 33042.4 \\
\hline Average household consumption during the reference year (Rs) & 15001.1 & 15533.2 & 15107.6 \\
\hline Coefficient of variation in income across households & 37.3 & 40.4 & 38.1 \\
\hline Coefficient of variation in consumption across households & 38.4 & 32.8 & 37.2 \\
\hline Gini coefficient of income & 0.19 & 0.21 & 0.20 \\
\hline Gini coefficient of consumption & 0.20 & 0.18 & 0.20 \\
\hline
\end{tabular}

Source: Field survey data

Table 3: Determinants of participation in NREGA at the household level Dependent variable: dummy participation in NREGA (Participation $=1$, Non-participation $=0$ )

\begin{tabular}{|c|c|c|c|c|}
\hline \multirow{2}{*}{ Variable name } & \multicolumn{2}{|c|}{ Logit function } & \multicolumn{2}{|c|}{ Probit function } \\
\hline & Coefficient & 'Z' value & Coefficient & 'Z' value \\
\hline Employment other than NREGA & $-0.0025861^{*}$ & -2.15 & $-0.0015375^{*}$ & -2.23 \\
\hline Household income other than NREGA & -0.0000209 & -1.24 & -0.0000108 & -1.13 \\
\hline Household size & 0.0128391 & 0.06 & 0.0053753 & 0.05 \\
\hline Land ownership dummy & 0.7832826 & 1.13 & 0.4128525 & 1.08 \\
\hline Value of household asset & -0.00000501 & -1.71 & -0.00000288 & -1.77 \\
\hline Dummy BPL card holding & $2.017466^{*}$ & 3.86 & $1.157678^{*}$ & 3.86 \\
\hline Dummy SC & 2.701574 & 1.64 & 1.394959 & 1.65 \\
\hline Dummy ST & $3.22174^{*}$ & 2.47 & $1.755185^{*}$ & 2.67 \\
\hline Dummy OBC & 2.414174 & 1.91 & 1.222214 & 1.95 \\
\hline Intercept & -1.083818 & -0.69 & -0.4234235 & -0.52 \\
\hline Number of observations & \multicolumn{2}{|c|}{200} & \multicolumn{2}{|c|}{200} \\
\hline Pseudo $\mathrm{R}^{2}$ & \multicolumn{2}{|c|}{0.3077} & \multicolumn{2}{|c|}{0.3141} \\
\hline Log likelihood & \multicolumn{2}{|c|}{-69.281938} & \multicolumn{2}{|c|}{-68.640622} \\
\hline LR Chi $^{2}$ (9) & \multicolumn{2}{|c|}{61.60} & \multicolumn{2}{|c|}{62.88} \\
\hline
\end{tabular}

Note: *indicates significant at 5\% level of significance

in case of non-beneficiary households, which is indicative of the fact that non-beneficiaries have derived income from occupations diversified in nature. In contrast, beneficiary households through their participations in NREGA activities derived more or less same income and thus produced lower degree of inequality in income within the group of beneficiaries. This suggests that creation of employment opportunities under NREGA has provided an impact on relative poverty by reducing income inequality.

In order to analyse the determinants of participation of members in NREGA, the Logit and Probit functions were used at the household as well as at the member level. In both the Logit and Probit regression models, dummy participation in NREGA (participation $=1$, non-participation $=0)$, has been taken as dependent variable. Tables-3 and 4 show the predictor variables (explanatory variables) used and its significant relation to the dependent variable. The estimated results are similar for both the models in case of household and member levels analysis. Value of $\mathrm{R}^{2}$ is also found to be low in both cases.

At the household level the predictor variables which were found significant are employment other than NREGA; dummy for BPL card holding and dummy for ST. Employment other than NREGA has a negative and significant coefficient implying that higher the involvement in activities other than NREGA, lower is the probability of participation in NREGA. The dummy for ST has a positive coefficient suggesting the STs are more likely to participate in NREGA compared to others. The dummy for BPL card holding is positively related 
Table 4: Determinants of participation in NREGA at the member level

Dependent variable: dummy participation in NREGA (Participation $=1$, Non-participation $=0$ )

\begin{tabular}{|c|c|c|c|c|}
\hline \multirow{2}{*}{ Variable name } & \multicolumn{2}{|c|}{ Logit function } & \multicolumn{2}{|c|}{ Probit function } \\
\hline & Coefficient & 'Z' value & Coefficient & 'Z' value \\
\hline Age & $0.0618644^{*}$ & 7.60 & $0.0294844^{*}$ & 7.37 \\
\hline Education & 0.1817126 & 1.25 & 0.09681 & 1.18 \\
\hline Household size & $-0.369583^{*}$ & -4.06 & $-0.2066503^{*}$ & -4.02 \\
\hline Dummy BPL card holding & 0.208017 & 0.50 & 0.1329398 & 0.55 \\
\hline Dummy sex & $0.5807665^{*}$ & 2.81 & $0.3357395^{*}$ & 2.82 \\
\hline Dummy SC & 1.179119 & 0.98 & 0.688554 & 0.92 \\
\hline Dummy ST & 1.254071 & 1.09 & 0.7270325 & 1.02 \\
\hline Dummy OBC & 1.000908 & 0.88 & 0.5930908 & 0.84 \\
\hline Intercept & -1.549798 & -1.15 & -0.7578844 & -0.92 \\
\hline Number of observations & \multicolumn{2}{|c|}{615} & \multicolumn{2}{|c|}{615} \\
\hline Pseudo $\mathrm{R}^{2}$ & \multicolumn{2}{|c|}{0.1395} & \multicolumn{2}{|c|}{0.1220} \\
\hline Log likelihood & \multicolumn{2}{|c|}{307.76289} & \multicolumn{2}{|c|}{-314.0292} \\
\hline $\operatorname{LR~Chi~}^{2}(8)$ & \multicolumn{2}{|c|}{99.78} & \multicolumn{2}{|c|}{87.29} \\
\hline
\end{tabular}

Note: ${ }^{*}$ indicates significant at $5 \%$ level of significance

Table 5: Determinants of participation in NREGA

Dependent variable: number of days per household worked in NREGA

\begin{tabular}{ccccc}
\hline Explanatory variables & Coefficient & $\begin{array}{c}\text { Standard error of } \\
\text { estimate }\end{array}$ & T value & $\begin{array}{c}\text { Significant/ } \\
\text { insignificant }\end{array}$ \\
\hline Intercept & 0.271375 & 0.1728178 & 1.57 & Insignificant \\
Employment other than NREGA (no of working days) & -0.0003473 & 0.0001518 & -2.29 & Significant \\
Household income other than NREGA $(₹)$ & -0.0000034 & 0.00000227 & -1.50 & Insignificant \\
Household size & 0.0114015 & 0.0223126 & 0.51 & Insignificant \\
Land holding dummy & 0.0936852 & 0.0794711 & 1.18 & Insignificant \\
Value of household assets $(₹)$ & -0.000000688 & 0.000000365 & -1.88 & Insignificant \\
Dummy for BPL card holding $(\mathrm{Y}=1, \mathrm{~N}=0)$ & 0.3641976 & 0.0741119 & 4.91 & Significant \\
Caste dummy for SC $(\mathrm{Y}=1, \mathrm{~N}=0)$ & 0.430197 & 0.177398 & 2.43 & Significant \\
Caste dummy for ST $(\mathrm{Y}=1, \mathrm{~N}=0)$ & 0.4603595 & 0.1420096 & 3.24 & Significant \\
Caste dummy for OBC $(\mathrm{Y}=1, \mathrm{~N}=0)$ & 0.3863103 & 0.139773 & 2.76 & Significant \\
\hline
\end{tabular}

$R^{2}=0.3366$, No. of observations $=200$, F value 10.71 with 9 and $199 \mathrm{df}$

to the household's participation in NREGA and has also turned out to be statistically significant. This suggests that larger the incidence of BPL card holders, higher the probability of participation in NREGA. The overall specification of the model is validated by the log likelihood based chi square test.

Member level Logit Probit estimates of regression coefficients are reported in Table-4. At the member level analysis the predictor variables included were age, education, household size and dummy variables like BPL card holding, sex, SC, ST and OBC. The results are similar for both the models.
Among the predictor variables, the coefficients relating to level of education, household size and sex turned out to be statistically significant. The level of education is positively related to NREGA participation. This implied that higher the level of education, higher the probability of participation in NREGA. Sex is having a positive impact on NREGA participation, which suggested that males had significantly high probabilities of participation in NREGA. Household size has a negative coefficient suggesting that the larger the household size, the lower is the probability of participation in NREG. 
Table 6: Determinants of participation in NREGA (member level OLS regression)

Dependent variable: number of days per household worked in NREGA

\begin{tabular}{ccccc}
\hline Explanatory variables & Coefficient & $\begin{array}{c}\text { Standard error of } \\
\text { estimate }\end{array}$ & T value & $\begin{array}{c}\text { Significant/ } \\
\text { insignificant }\end{array}$ \\
\hline Intercept & 0.2011546 & 0.2498934 & 0.80 & Insignificant \\
Age in years & 0.0102909 & 0.0012039 & 8.55 & Significant \\
Level of Education & 0.0390281 & 0.0241432 & 1.62 & Insignificant \\
Household size (no) & -0.0630826 & 0.0145579 & -4.33 & Significant \\
Dummy for BPL card holding $(\mathrm{Y}=1, \mathrm{~N}=0)$ & 0.044918 & 0.0701398 & 0.64 & Insignificant \\
Sex dummy (male=1, female=0) & 0.1048945 & 0.0341641 & 3.07 & Significant \\
Dummy for SC $(\mathrm{Y}=1, \mathrm{~N}=0)$ & 0.2253409 & 0.2284426 & 0.99 & Insignificant \\
Dummy for ST $(\mathrm{Y}=1, \mathrm{~N}=0)$ & 0.2466023 & 0.2201742 & 1.12 & Insignificant \\
Dummy for OBC $(\mathrm{Y}=1, \mathrm{~N}=0)$ & 0.2028719 & 0.2182388 & 0.93 & Insignificant \\
\hline
\end{tabular}

$R^{2}=0.1499$, No. of observations $=615, F$ value 13.36 with 8 and $614 d f$.

The log likelihood based chi-square test used for testing goodness of fit suggests that the model used is a good predictor model.

The results of the household level OLS estimates are presented in Table 5. It can be seen that the variables which are positively and significantly related to the dependent variable are dummy for BPL card holding and caste dummies for SC, ST and OBC. The positive coefficient for BPL card holding implied that holding of BPL cards influenced employment under NREGA. Caste dummies have positive coefficients suggesting that SC, ST and OBCs have more participation days in NREGA compared to other castes. The statistically significant variable, employment other than NREGA has negative influence on NREGA employment suggesting that households having employment other than NREGA are likely to have lesser NREGA working days compared to others.

At the member level analysis (Table 6), the explanatory variables included the continuous variables like age (in years), level of education, household size (number) and the dummy variables inclusive of dummy for BPL card holding, sex dummy, dummies for SC, ST and OBC. At the individual member level, the variables which were found to be statistically significant included age, household size, and sex dummy. Of them, household size is found to statistically influence NREGA employment negatively suggesting that larger the household size, the lower is the NREGA participation days. The positive coefficient for age implied that aged persons participated more in NREGA employment. Sex dummy has positive coefficient suggesting that male members participated more in NREGA than females.

\section{CONCLUSION}

There is considerable amount of variation across the households in the consumption of food and non-food items between beneficiary and nonbeneficiary households under NREGA in Sikkim. The average household consumption expenditure is lower than household income both for beneficiary and non-beneficiary households. There are however variations in income and consumption across the households and the extent of variation being greater for non-beneficiary households. There is relatively greater inequality in the income earned in case of non-beneficiary households, which is indicative of the fact that non-beneficiaries have derived income from occupations diversified in nature. The level of education and sex are positively related to NREGA participation. Household size has a negative coefficient suggesting that the larger the household size, the lower is the probability of participation in NREGA.

\section{REFERENCES}

Ambasta, P., Shankar, P.S.V. and Mihir Shah 2008. "Two years of NREGA: The Road Ahead", Economic and Political Weekly, 43(8).

Chakraborty, Pinaki 2007. “Implementation of employment guarantee: A preliminary appraisal", Economic and Political Weekly, February 17. 
Gopal, K.S. 2008. NREGA and Social Audits-myths and Reality, Economic and Political Weekly, January 27.

Jha, R., Gaiha, R. and Shankar, S. 2008. "Reviewing the National Rural Employment Guarantee Programme". Economic and Political Weekly, 43(10): 44-48.
Mehrotra, Santosh 2008. "NREG two years on: where do we go from here?" Economic and Political Weekly, August 2. 
